\title{
Efektivitas Pemberian Antibiotik Disertai Lansoprazol pada Refluks Laringofaring dengan Infeksi Helicobacter pylori
}

\author{
Yanti Nurrokhmawati, ${ }^{1}$ Teti Madiadipoera, ${ }^{2}$ Ratna Anggraeni A., ${ }^{2}$ \\ Tonny Basriyadi Sarbini ${ }^{2}$ \\ ${ }^{1}$ Rumah Sakit Dustira Cimahi, ${ }^{2}$ Departemen Ilmu Kesehatan Telinga, Hidung, Tenggorok, Be- \\ dah Kepala, dan Leher Fakultas Kedokteran Universitas Padjadjaran-Rumah Sakit Dr. Hasan \\ Sadikin Bandung
}

\begin{abstract}
Abstrak
Refluks laringofaring adalah aliran balik isi lambung ke daerah laringofaring dan dapat dipengaruhi oleh infeksi Helicobacter pylori. Regimen terapi untuk infeksi H. pylori terdiri atas proton pump inhibitor (PPI) dan dua jenis antibiotik yaitu amoksisilin dan klaritromisin. Peran PPI pada regimen ini masih diteliti. Dilakukan penelitian mengenai perbandingan efektivitas terapi antibiotik disertai PPI (lansoprazol) terhadap perbaikan gejala klinis dan kualitas hidup penderita refluks laringofaring dengan infeksi H. pylori. Penelitian ini dilakukan di Departemen THT-KL RS Dr. Hasan Sadikin Bandung periode September 2009-Desember 2010 merupakan randomized clinical trial dengan pengamatan open label.Data dianalisis dengan menggunakan uji t dan uji Mann Whitney.Penelitian ini melibatkan 26 subjek penelitian yang dibagi menjadi dua kelompok. Kelompok pertama diberikan regimen terapi H. pylori, berupa klaritromisin dan amoksisilin dengan lansoprazol dan kelompok kedua diberikan klaritromisin dan amoksisilin tanpa lansoprazol. Dilakukan pemeriksaan skor gejala refluks (SGR), skor temuan refluks (STR), dan penilaian kualitas hidup dengan kuesioner reflux qual short-form (RQS). Evaluasi dilakukan setelah 2 minggu. Didapatkan perbedaan bermakna $(\mathrm{p}=0,034)$ skor SGR pascaterapi pada kelompok perlakuan antibiotik kombinasi dengan lansoprazol. Tidak didapatkan perbedaan bermakna $(\mathrm{p}=0,169)$ pada perbaikan STR pascaterapi. Perbaikan skor RQS lebih baik pada kelompok perlakuan pertama dibandingkan dengan kelompok kedua $(p=0,018)$. Disimpulkan bahwa pemberian campuran antibiotik kombinasi dan lansoprazol lebih efektif terhadap perbaikan gejala klinis dan kualitas hidup dibandingkan dengan tanpa lansoprazol. [MKB. 2012;44(4):224-32].
\end{abstract}

Kata kunci: Helicobacter pylori, kualitas hidup, lansoprazol, refluks laringofaring

\section{The Effectiveness of Antibiotics with Lansoprazole in the Treatment of Laryngopharyngeal Reflux with Helicobacter pylori Infection}

\begin{abstract}
Laryngopharyngeal Reflux (LPR) is a reflux of gastric content to the laryngopharyngeal and influenced by Helicobacter pylori infection. The treatment of $\mathrm{H}$. pylori infection consists of proton pump inhibitor and two kinds of antibiotics, i.e. amoxicillin and clarithromycin. The role of PPI is currently being studied. The objectives of the research were to compare the effectiveness of antibiotics regimen with and without lansoprazole in reducing the level of the severity and quality of life improvement in LPR patients with H. pylori infection. Twenty six subjects were divided into two groups; the first group received antibiotics with lansoprazole and the second group received antibiotics without lansoprazole. The research subjects were assessed using reflux symptom index (RSI) questionnaire and reflux finding score (RFS) while the assessment on the quality of life was performed using reflux qual short-form (RQS) questionnaire. These data were obtained at baseline and after 2 weeks of treatment. The method was randomized clinical trial with open label observation and the analysis was conducted using $\mathrm{t}$ and Mann Whitney tests. There was a significant improvement in the RSI post treatment in the first group $(\mathrm{p}=0.034)$. The difference in RFS was not significantly different statistically between both groups $(\mathrm{p}=0.169)$. The RQS was significantly better statistically in the first group $(p=0.018)$. It is concluded that treatment regimen with claritromicin, amoxycillin and lansoprazole is more effective in the treatment of LPR associated with H. pylori infection compared to without lansoprazole. [MKB. 2012;44(4):224-32].
\end{abstract}

Key words: Helicobacter pylori, laryngopharyngeal reflux, lansoprazole, quality of life

Korespondensi: Yanti Nurrokhmawati, dr., Sp.THT, Rumah Sakit Dustira Cimahi, jalan Dr. Dustira 1 Cimah Selatan Cimahi, mobile 081394369359, e-mail yantinurrokhmawati@yahoo.co.id 


\section{Pendahuluan}

Refluks laringofaring merupakan aliran balik isi lambung ke laringofaring sebagai spektrum dari gastroesophageal reflux disease (GERD) yang memengaruhi laring dan faring. Diagnosis refluks laringofaring dapat ditegakkan bedasarkan reflux symptom index (RSI)/skor gejala refluks (SGR). Kriteria refluks laringofaring bila skor $>13$, reflux finding score (RFS)/skor temuan refluks (STR) bila skor $>7 . .^{1-4}$

Prevalensi refluks laringofaring yaitu 15$20 \%$. Secara epidemiologis prevalensi infeksi oleh Helicobater pylori sekitar 30-40\% di negara berkembang, sedangkan di negara miskin antara $80 \%$ sampai $90 \%$. Refluks laringofaring memiliki dampak terhadap kualitas hidup penderita secara fisik, ekonomi, dan sosial. ${ }^{1,5}$

Mekanisme terjadi jejas pada laringofaring disebabkan oleh kontak langsung laring dengan bahan asam, pepsin, dan bahan nonasam lain, serta stimulasi nervus aferen vagal di distal esofagus. ${ }^{2,3}$ Infeksi $H$. pylori mempunyai pengaruh GERD dapat berupa sekresi lower eresophageal sphincter (LES) relaxing cytotoxins, prostaglandin, dan nitrat oksida oleh $H$. pylori, terjadi sensitisasi vagal yang dapat menurunkan ambang transient lower esophageal sphincter relaxation (TLESR), terjadi peningkatan sekresi gastrin, keterlambatan pengosongan isi lambung, serta trauma langsung akibat sitotoksin yang dikeluarkan oleh $H$. pylori pada mukosa esofagus. ${ }^{6,7}$

Mendeteksi infeksi $H$. pylori terbagi menjadi dua kelompok, invasif dan noninvasif. Tes invasif meliputi endoskopi dengan cara biopsi, kemudian dilakukan pemeriksaan histologi, aktivitas urease Campylobacter like organism (CLO) disertai kultur. Pemeriksaan ini mempunyai sensitivitas dan spesifisitas tinggi namun invasif, memerlukan pemeriksaan endoskopi yang mahal dan kurang nyaman serta dapat menimbulkan komplikasi. Pemeriksaan noninvasif terdiri atas $\mathrm{C} 13$ urea breath test, serologi, dan tes antigen dari feses. C13 urea breath test merupakan standar baku tes noninvasif, namun relatif mahal dan bergantung pada ketersediaan alat ini. Tes antigen dari feses merupakan alternatif tes noninvasif terpilih karena dapat mendeteksi infeksi aktif dengan sensitivitas dan spesifisitas yang tinggi. ${ }^{8}$ Helicobacter pylori stool antigen ( $\mathrm{HpSA}$ ) adalah suatu pemeriksaan enzim untuk mendeteksi antigen $H$. pylori di dalam feses. Tes HpSA ini telah divalidasi dengan hasil sensitivitas $88 \%$ dan spesifisitas $87,5 \%{ }^{8}$

Proton pump inhibitor (PPI) sebagai obat antirefluks paling efektif dan efeknya langsung terhadap $\mathrm{H}^{+} \mathrm{K}^{+}$ATPase yang merupakan enzim pompa proton pada jalur akhir produksi asam dari sel parietal. Obat ini mengurangi produksi asam dan aktivitas pepsin sehingga kerusakaan jaringan dicegah. ${ }^{9}$ Lansoprazol adalah golongan PPI yang memiliki tingkat bioavailabilitas tinggi, waktu konsentrasi puncak plasma tinggi, harga ekonomis, dan memiliki efek samping minimal. ${ }^{9}$

Banyak penelitian menyatakan bermacam regimen untuk terapi infeksi $H$. pylori. Kombinasi ini terdiri atas terapi dual, triple atau quadriple. Kombinasi ini bertujuan untuk memaksimalkan kemampuan eradikasi $H$. pylori, meminimalkan risiko resistensi antimikrob, dan memungkinkan masa pemberian yang pendek sehingga mampu meningkatkan kepatuhan. Golongan penisilin, khususnya amoksisilin adalah antibiotik yang paling banyak dipakai untuk regimen pengobatan infeksi $H$. pylori. Di samping efek bakterisida, amoksisilin juga mampu merusak dinding selsel bakteri. Amoksisilin juga dapat menginduksi ekspresi beberapa sitokin.Pemberian amoksisilin dapat menurunkan IL-6, tumour necrosis factor- $\alpha$, dan IL-10. Konsentrasi amoksisilin paling tinggi dalam cairan dan mukosa gaster dicapai dengan dosis 2 gram per hari. ${ }^{10}$

Klaritromisin merupakan antibiotik golongan makrolid yang paling banyak digunakan dalam regimen eradikasi $H$. pylori, juga menghasilkan efek antibakteri dengan berikatan pada ribosom bakteri. Keadaan ini akan menganggu sintesis protein bakteri tersebut. Klaritromisin dihasilkan dengan mensubstitusikan methoxy group dari C-6 hydroxyl group eritromisin, substistusi ini menghasilkan efek antimikrob yang stabil dalam suasana asam. Secara in vitro dari kultur sel epitel hidung manusia, pemberian makrolid dapat menghambat sekresi IL-8 yang diinduksi oleh lipopolisakarida (LPS). ${ }^{12}$ Pada infeksi gramnegatif, LPS mengaktivasi monosit yang akhirnya akan memproduksi IL-8 dan akan merangsang penarikan sel-sel inflamasi pada tempat infeksi. Makrolid mampu menekan IL-8 melalui activator protein-1 (AP-1) dan nuclear factor- $\kappa B$ (NF- $\kappa \mathrm{B})$ pada sel-sel epitel. Ekstrak beberapa bakteri di antaranya $H$. pylori menginduksi produksi IL- $8 .{ }^{11}$

Banyak penelitian mengenai peranan proton pump inhibitor untuk eradikasi $H$. pylori. Proton pump inhibitor secara potensial dapat mengubah farmakokinetik antibiotik dengan menurunkan viskositas/volume asam lambung, menurunkan pengosongan lambung, memengaruhi stabilitas obat, dan kemungkinan mengurangi pemecahan bentuk padat obat. Dalam penelitian Ortiz dan Calafatti, ${ }^{12}$ pemberian lansoprazol menurunkan konsentrasi puncak plasma $\left(\mathrm{C}_{\mathrm{MAX}}\right)$ dan area under curve (AUC) klaritromisin pada penderita infeksi H. pylori. Pada penelitian ini dipertimbangkan apakah pemberian PPI dalam regimen terapi perlu diberikan secara simultan atau setelah eradikasi $H$. pylori. ${ }^{12-14}$ Gustauson dkk. ${ }^{15}$ menyatakan terdapat 
efek sinergi antara antibiotik dan lansoprazol dalam eradikasi $H$. pylori.

\section{Metode}

Subjek penelitian adalah penderita refluks laringofaring di Departemen THT KL RS Dr. Hasan Sadikin Bandung periode September 2009 sampai Desember 2010 sesuai kriteria inklusi dan tidak termasuk kriteria eksklusi yang bersedia ikut serta dalam penelitian. Usia $>18$ tahun, penderita refluks laringofaring dengan kriteria SGR $>13$, STR $>7$, dan hasil tes HpSA positif.

Kriteria eksklusi yaitu penderita yang telah mendapat eradikasi $H$. pylori sebelumnya, riwayat menderita kanker pada daerah kepala dan leher, riwayat menjalani radioterapi di daerah leher sebelumnya, riwayat pemasangan endotracheal tube (ETT) dalam dua bulan terakhir, alergi obat PPI, amoksisilin, dan klaritromisin.

Besar sampel ditentukan berdasarkan taraf kepercayaan $95 \%$ dan power test $80 \%$. Penelitian ini merupakan penelitian randomized clinical trial dengan pengamatan open label. Alokasi ke dalam perlakuan dilakukan secara random blok per mutasi. Variabel yang diukur adalah gejala klinis laringofaring berdasarkan SGR, keadaan patologis laring berdasarkan STR, dan kualitas hidup penderita refluks laringofaring berdasarkan RQS. Subjek yang memenuhi kriteria penelitian diberikan penjelasan tentang prosedur penelitian yang akan dilakukan. Apabila subjek setuju dan mengertitentangprosedurkeikutsertaanpenelitian, kemudian menandatangani persetujuan untuk ikut serta dalam penelitian (informed consent).

Setelah setuju, dilakukan pemeriksaan indeks SGR yang memenuhi kriteria $>13$, skor STR $>7$, dan penderita diminta untuk mengisi kuesioner RQS, kemudian dilakukan pemeriksaan HpSA. Tes HpSA merupakan tes kualitatif menggunakan antibodi poliklonal kelinci. Prosedur dilakukan dengan menyediakan $10 \mathrm{~mL}$ sampel feses yang dilarutkan dalam $0,5 \mathrm{~mL}$ cairan, lalu cairan peroxidase conjugated polyclonal antibody dimasukkan ke dalam larutan ini dan diinkubasi satu jam pada suhu ruangan. Antigen $H$. pylori dapat dideteksi dengan melihat perubahan warna. Diberikan cairan penghenti, kemudian hasil dibaca pada spektrofotometer. Hasil diinterpretasikan sebagai negatif bila OD450<0,140 dan positif bila OD450>0,160 ${ }^{16}$

Subjek dengan hasil HpSA positif kemudian dibagi dalam dua kelompok. Kelompok pertama diberikan terapi lansoprazol $2 \times 30 \mathrm{mg}$, amoksisilin $2 \times 1 \mathrm{~g}$, dan klaritromisin $2 \times 500 \mathrm{mg}$ selama 14 hari. Kelompok kontrol diberikan amoksisilin 2x1 g dan klaritromisin 2x500 mg selama 14 hari. Setelah terapi 14 hari pada penderita dilakukan pemeriksaan ulang SGR, STR, RQS, dan HpSA untuk menilai keberhasilan terapi, pemeriksaan merupakan data akhir dan dilakukan analisis data dengan menggunakan program SPSS versi 13.

\section{Hasil}

Dalam periode penelitian didapat 70 penderita refluks laringofaring. Dari 70 penderita refluks laringofaring tersebut dilakukan tapisan sesuai kriteria inklusi dan eksklusi. Dilakukan pengisian kuesioner SGR, STR, RQS, serta pemeriksaan HpSA.

Hasil HpSA positif (37\%) ditemukan pada 26 dari 70 penderita. Pengamatan dilakukan sebelum terapi dan setelah diberikan terapi selama 14 hari.

Pada 26 subjek penelitian, didapatkan jenis kelamin perempuan lebih banyak dibandingkan dengan laki-laki dan usia $>40$ tahun lebih banyak bila dibandingkan dengan usia $<40$ tahun. Dinilai juga perbandingan indeks massa tubuh pada kedua kelompok. Hasil analisis statistik disimpulkan bahwa subjek penelitian ini homogen, sehingga layak untuk diperbandingkan (Tabel 1).

Keluhan refluks berdasarkan SGR terbanyak adalah mendehem dan dahak di tenggorokan ditemukan pada semua subjek (Tabel 2).

Amoksisilin, klaritromisin, dan lansoprazol diberikan pada kelompok pertama, sedangkan kelompok kedua hanya diberikan amoksisilin dan klaritromisin, kemudian dilakukan penilaian SGR pascaterapi. Berdasarkan hasil penghitungan analisis statistik pada kedua kelompok penelitian pascaterapi didapatkan perbedaan yang bermakna $(p<0,05)$ pada keluhan serak dan rasa mengganjal, dan tidak bermakna $(p>0,05)$ pada keluhan lain.

Dilakukan perbandingan skor SGR kedua kelompok penelitian praterapi serta pascaterapi. Berdasarkan analisis statistik kedua kelompok penelitian tidak didapatkan perbedaan bermakna $(p=0,336)$ dalam penilaian praterapi, namun berbeda bermakna $(p=0,034)$ perbaikan skor SGR pascaterapi pada kelompok perlakuan antibiotik kombinasi dengan lansoprazol (Tabel 3).

Pada pemeriksaaan rinolaringoskopi serat lentur dinilai kelainan anatomis laring. Hasilnya dinilai menggunakan skor temuan refluks (STR). Hasil pemeriksaan anatomis laring yang terbanyak adalah eritema/hiperemis dan edema pita suara pada semua penderita. Ditemukan perbaikan skor STR pada kedua kelompok perlakuan dan masing-masing domain pemeriksaan. Ditemukan perbaikan skor pada hampir seluruh domain pada STR, namun berdasarkan hasil analisis statistik kedua kelompok penelitian pascaterapi 
Yanti N.: Efektivitas Pemberian Antibiotik Disertai Lansoprazol pada refluks Laringofaring dengan Infeksi Helicobacter pylori

Tabel 1 Karakteristik Subjek Penelitian

\begin{tabular}{|c|c|c|c|}
\hline \multirow{2}{*}{ Karakteristik } & \multicolumn{2}{|c|}{ Perlakuan } & \multirow{2}{*}{ Kemaknaan } \\
\hline & Kelompok I $(n=13)$ & Kelompok II $(n=13)$ & \\
\hline \multicolumn{4}{|l|}{ Jenis kelamin } \\
\hline Laki-laki & 4 & 3 & $\mathrm{p}=0,658^{*}$ \\
\hline Perempuan & 9 & 10 & \\
\hline Usia (tahun) & & & $\mathrm{p}=0,519 * *$ \\
\hline$<40$ & 3 & 3 & \\
\hline $40-49$ & 3 & 3 & \\
\hline $50-59$ & 5 & 6 & \\
\hline$>60$ & 2 & 1 & \\
\hline Rerata & 47,4 & 43,8 & \\
\hline Rentang & $19-63$ & $25-64$ & \\
\hline BMI & 25,69 & 26,00 & $\mathrm{p}=0,829 * *$ \\
\hline
\end{tabular}

Tabel 2 Karakteristik Keluhan Refluks pada Subjek Penelitian

\begin{tabular}{|c|c|c|c|}
\hline Keluhan & $\begin{array}{c}\text { Kelompok I } \\
\text { n } \\
\end{array}$ & $\begin{array}{c}\text { Kelompok II } \\
\mathbf{n}\end{array}$ & $\begin{array}{c}\text { Total } \\
\text { n }\end{array}$ \\
\hline Serak & 12 & 12 & 24 \\
\hline Mendehem & 13 & 13 & 26 \\
\hline Dahak di tenggorokan & 13 & 13 & 26 \\
\hline Kesukaran menelan & 11 & 84 & 22 \\
\hline Batuk setelah makan/berbaring & 13 & 92 & 15 \\
\hline Kesukaran bernapas/choking & 9 & 11 & 20 \\
\hline Batuk yang mengganggu & 11 & 12 & 23 \\
\hline Rasa mengganjal di tenggorokan & 12 & 12 & 24 \\
\hline Nyeri dada/regurgitasi asam & 12 & 13 & 25 \\
\hline
\end{tabular}

Keterangan: $n=$ jumlah subjek penelitian; satu penderita dapat mempunyai satu atau lebih keluhan di atas

tidak ditemukan perbedaan bermakna perbaikan skor STR. Terdapat perbaikan skor STR pada kelompok perlakuan antibiotik dengan lansoprazol pada praterapi (median 12) serta pascaterapi (median 4). Demikan juga pada kelompok perlakuan kombinasi antibiotik tanpa lansoprazol, ditemukan perbaikan skor STR pada praterapi (median 13) dan pascaterapi (median
5) (Tabel 5). Berdasarkan hasil analisis statistik dengan uji Mann-Whitney pada kedua kelompok penelitian tidak didapatkan perbedaan bermakna $(\mathrm{p}=0,169)$ perbaikan skor STR praterapi dan pascaterapi pada kedua kelompok penelitian (Tabel 5). Dilakukan pemeriksaan tingkat kualitas hidup pada kedua kelompok penelitian, penderita diminta mengisi kuisioner RQS (Reflux qual

Tabel 3 Perbandingan Skor Gejala Refluks (SGR) antara Pemeriksaan Praterapi dan Pascaterapi

\begin{tabular}{|c|c|c|c|c|c|}
\hline & & \multicolumn{2}{|c|}{ Perlakuan } & \multirow[b]{2}{*}{$\mathbf{Z}_{\mathrm{MW}}$} & \multirow[b]{2}{*}{$\mathbf{p}$} \\
\hline \multicolumn{2}{|c|}{ SGR } & $\begin{array}{c}\text { Kelompok I } \\
(n=13)\end{array}$ & $\begin{array}{c}\text { Kelompok II } \\
(n=13)\end{array}$ & & \\
\hline Praterapi & $\begin{array}{l}\text { Median } \\
\text { Rentang }\end{array}$ & $\begin{array}{c}21 \\
14-33\end{array}$ & $\begin{array}{c}23 \\
16-27\end{array}$ & 1,007 & 0,336 \\
\hline Pascaterapi & $\begin{array}{l}\text { Median } \\
\text { Rentang }\end{array}$ & $\begin{array}{c}6 \\
3-13\end{array}$ & $\begin{array}{c}10 \\
6-14\end{array}$ & 2,117 & 0,034 \\
\hline
\end{tabular}

Keterangan $_{\mathrm{m}-\mathrm{w}}=$ uji Mann- Whitney; GR = skor gejala refluks 
Yanti N.: Efektivitas Pemberian Antibiotik Disertai Lansoprazol pada refluks Laringofaring dengan Infeksi Helicobacter pylori

Tabel 4 Karakteristik Kelainan Anatomis Laring pada Subjek Penelitian

\begin{tabular}{lccc}
\hline \multirow{2}{*}{ Kelainan Anatomis Laring } & Kelompok I & Kelompok II & Total \\
\cline { 2 - 4 } & $\mathbf{n}$ & $\mathbf{n}$ & $\mathbf{n}$ \\
\hline Edema subglotik & 7 & 7 & 14 \\
Obliterasi ventrikular & 9 & 10 & 19 \\
Eritema/hiperemis & 13 & 13 & 26 \\
Edema pita suara & 12 & 12 & 24 \\
Edema laring menyeluruh & 13 & 11 & 24 \\
Hipertrofi komisura posterior & 13 & 13 & 26 \\
Granuloma & 0 & 0 & 0 \\
Mukus endolaring & 12 & 12 & 24 \\
\hline
\end{tabular}

Keterangan: $n=$ jumlah subjek penelitian, satu penderita dapat mempunyai satu atau lebih kelainan di atas

short-form). Hasil penghitungan statistik dengan uji Mann-Whitney.

Kedua kelompok perlakuan tidak didapatkan perbedaan yang bermakna $(\mathrm{p}>0,05)$ sebelum dilakukan terapi(Tabel6). Setelah menjalani terapi selama 14 hari pada kedua kelompok perlakuan didapatkan perbedaan hasil RQS, yang artinya terdapat perbaikan kualitas hidup pascaterapi. Berdasarkan analisi statistik didapatkan perbedaan bermakna $(\mathrm{p}=0,002)$ perbaikan skor RQS pada kelompok perlakuan antibiotik kombinasi dengan lansoprazol. Terdapat perbaikan yang bermakna pada domain gangguan fungsi fisik $(\mathrm{p}=0,001)$ dan ketidaknyamanan $(\mathrm{p}=0,014)$.

Tabel 5 Perbandingan Skor Temuan Refluks antara Pemeriksaan Praterapi dan Pascaterapi

\begin{tabular}{|c|c|c|c|c|c|}
\hline \multirow{2}{*}{\multicolumn{2}{|c|}{ Skor Temuan Refluks }} & \multicolumn{2}{|c|}{ Perlakuan } & \multirow[b]{2}{*}{ ZMW } & \multirow[b]{2}{*}{$\mathbf{p}$} \\
\hline & & $\begin{array}{c}\text { Kelompok I } \\
(n=13)\end{array}$ & $\begin{array}{c}\text { Kelompok II } \\
(n=13)\end{array}$ & & \\
\hline \multirow[t]{2}{*}{ Praterapi } & Median & 12 & 13 & 0,66 & 0.545 \\
\hline & Rentang & $8-16$ & $10-16$ & & \\
\hline \multirow[t]{2}{*}{ Pascaterapi } & Median & 4 & 5 & 1 & 0.169 \\
\hline & Rentang & $2-8$ & $2-12$ & & \\
\hline
\end{tabular}

Keterangan: $Z_{\text {m-w }}=$ uji Mann-Whitney, STR=skor temuan refluks

Tabel 6 Hasil Reflux Qual Short-form pada Pemeriksaan Praterapi

\begin{tabular}{|c|c|c|c|c|}
\hline \multirow[b]{2}{*}{ Variabel } & \multicolumn{2}{|c|}{ Reflux Qual Short-form } & \multirow[b]{2}{*}{$\mathbf{Z}_{\mathrm{MW}}$} & \multirow[b]{2}{*}{$\mathbf{p}$} \\
\hline & $\begin{array}{c}\text { Kelompok I } \\
(n=13)\end{array}$ & $\begin{array}{c}\text { Kelompok II } \\
(n=13)\end{array}$ & & \\
\hline Keterbatasan emosi & $3(2-4)$ & $4(3-4)$ & 0,108 & 0,920 \\
\hline Gangguan kesehatan mental & $4(3-4)$ & $4(3-4)$ & 0,524 & 0,687 \\
\hline Gangguan fungsi fisik & $3(2-4)$ & $3(3-4)$ & 1,185 & 0,287 \\
\hline Keterbatasan fungsi fisik & $3(2-4)$ & $2(2-4)$ & 1,102 & 0,362 \\
\hline Gangguan vitalitas & $3(2-4)$ & $3(3-4)$ & 0,26 & 0,840 \\
\hline Ketidaknyamanan & $3(1-4)$ & $3(3-4)$ & 0,335 & 0,762 \\
\hline Gangguan fungsi sosial & $3(2-4)$ & $3(3-4)$ & 0,868 & 0,448 \\
\hline Persepsi kesehatan umum & $3(2-4)$ & $2(2-4)$ & 1,11 & 0,311 \\
\hline Skor total & $23(20-28)$ & $24(20-32)$ & 0,726 & 0,479 \\
\hline
\end{tabular}

Keterangan: $Z_{\mathrm{m}-\mathrm{w}}=$ uji Mann-Whitney, RQS=reflux qual-short form 
Berdasarkan hasil analisis statistik pada kedua kelompok penelitian ini didapatkan perbedaan bermakna $(p=0,018)$ perbaikan skor RQS pada kelompok perlakuan antibiotik kombinasi dengan lansoprazol.

\section{Pembahasan}

Subjek penelitian terdiri atas 19 orang perempuan dari 7 laki-laki. Hal ini disebabkan oleh karena faktor hormonal yang memengaruhi hipotalamus, kelenjar pituitari anterior, dan adreno corticotropic hormone (ACTH) sehingga kelenjar adrenal menghasilkan kortison yang akan menstimulasi sel parietal dan kelenjar peptik untuk menghasilkan HCI dan pepsin. Selain itu, pembentukan asam lambung di sel parietal juga dipengaruhi oleh berbagai faktor yang lain di antaranya faktor pola hidup, faktor kegemukan, serta faktor psikis. ${ }^{1,3}$ Pada penelitian ini persentase usia subjek lebih tinggi pada usia $>40$ tahun. Hal ini dipengaruhi oleh beberapa hal, misalnya pola hidup, faktor kegemukan, dan psikis. Pada usia $>40$ tahun keadaan laring menjadi rentan apabila terpapar zat asam sehingga meningkatkan angka kejadian kasus refluks laringofaring. Secara histologis pada usia tua sedikit ditemukan granular retikulum endoplasmik dan aparatus Golgi pada mukus dan serosa pada laring, sehingga secara kualitas dan kuantitas sekresinya berkurang. Selain itu, pada usia tua produksi saliva dan mukus berkurang. Perubahan juga terjadi pada mukosa epitel plika vokalis menjadi lebih tipis..$^{1-3}$

Secara global, infeksi $H$. pylori meningkat progresif sejalan dengan faktor usia, namun di negara berkembang, infeksi $H$. pylori justru lebih banyak terjadi pada usia muda. ${ }^{5}$ Pada praterapi dilakukan penilaian gejala dengan menggunakan kuesioner SGR. ${ }^{4}$ Keluhan terbanyak yang didapat berupa mendehem dan dahak di tenggorokan pada semua subjek penelitian. Hasil ini berbeda dengan hasil penelitian oleh Fouad dkk. ${ }^{7}$ yang meneliti gejala pada penderita refluks laringofaring dengan infeksi $H$. pylori didapatkan keluhan suara serak $(24 \%)$, batuk kronik $(68 \%)$, mendehem $(46 \%)$, rasa mengganjal di tenggorokan (52\%), dan regurgitasi asam (40\%). Pada penelitian ini tidak terdapat perbedaan bermakna keluhan refluks laringofaring antara penderita dengan dan tanpa infeksi $H$. pylori. ${ }^{7}$

Keluhan refluks laringofaring yang dirasakan oleh penderita tersebut disebabkan tidak terdapat mekanisme pertahanan zat asam di daerah saluran napas atas sehingga dalam jumlah yang sedikitpun dapat menyebabkan gejala refluks laringofaring yang signifikan. Laring lebih sensitif sekitar 100 kali terhadap kerusakan oleh pepsin dibandingkan dengan esofagus dan tiga kali episode refluks per minggu sudah mampu menyebabkan kerusakan laring yang signifikan. ${ }^{2,3,16}$

Pada penelitian didapatkan sekret di belakang hidung pada semua penderita. Keluhan sekret di belakang hidung atau post nasal drip berhubungan dengan terpaparnya faring dan nasofaring oleh refluks asam yang menimbulkan sensasi sekret di belakang hidung atau sensasi hidung tersumbat, serta akan meningkatkan keadaan sekresi nasal. Bila mekanisme pertahanan laring menghilang, disfungsi silia akan menyebabkan penumpukan mukus menghasilkan sensasi sekret di belakang hidung serta menginduksi mendehem. Akumulasi sekret dan zat asam akan menyebabkan iritasi pada saraf sensori laring yang sangat sensitif sehingga akan menimbulkan gejala batuk dan tersedak. ${ }^{16,17}$

Keluhan heartburn tidak terlalu banyak ditemukan pada penderita refluks laringofaring. Pada penelitian lain didapatkan keluhan rasa terbakar di dada $(95,7 \%)$ pada semua penderita. Hal ini disebabkan patogenesis infeksi $H$. pylori terhadap LPR, infeksi $H$. pylori menyebabkan pelepasan lower esophageal sphincter (LES) relaxing cytotoxins, prostaglandin dan nitrat oksida, juga disertai penurunan transient lower esophageal sphincter relaxation (TLESR). Hal ini merupakan patogenesis GERD, sehingga pada refluks laringofaring kemungkinan keluhan nyeri dada/heartburn akan lebih tinggi dibandingkan dengan penderita refluks laringofaring tanpa infeksi H. pylori. ${ }^{2,6,7,16}$

Pada kedua kelompok penelitian pascaterapi didapatkan perbaikan keluhan serak serta rasa mengganjal di tenggorokan yang lebih baik bila dibandingkan dengan kelompok perlakuan kombinasi antibiotik dan lansoprazol, sedangkan perbaikan gejala refluks lainnya tidak ditemukan perbedaan.Secara keseluruhan, perbaikan gejala didapatkan lebih baik pada kelompok perlakuan pertama.

Kelainan laring yang terbanyak berdasarkan STR adalah eritema/hiperemis serta hipertrofi komisura posterior pada semua subjek penelitian. Pascaterapi didapatkan perbaikan pada kedua kelompok, namun tidak bermakna secara statistik.

Kelainan anatomis laring yang didapatkan pada penelitian ini hampir sama dengan penelitian sebelumnya. Keadaan ini didukung oleh analisis para peneliti yang menyatakan bahwa gejala tersebut spesifik untuk kelainan yang disebabkan oleh iritasi dan inflamasi laring. Hal ini menunjang diagnosis refluks laringofaring. Gambaran laring pada pemeriksaan laringoskopi yang spesifik untuk refluks laringofaring berupa edema dan eritema dinding krikoid posterior, dinding medial aritenoid, dan pita suara. Gambaran yang kurang 
spesifik yaitu granula dengan atau tanpa cobble stoning, ulkus, polip atau granuloma. ${ }^{1-3}$

Fouad dkk. ${ }^{7}$ membuktikan pada penderita refluks laringofaring dengan infeksi $H$. pylori didapatkan eritema aritenoid (56\%), ulkus laring $(12 \%)$, edema plika vokalis (28\%), dan granuloma laring $(4 \%)$. Penelitian ini juga membandingkan keluhan tersebut dengan status infeksi $H$. pylori yang diperiksa dengan HpSA. Hasilnya ternyata tidak terdapat perbedaan signifikan antara jenis kelainan anatomis laring dan status infeksi $H$. pylori. ${ }^{6,7}$

Eritema/hiperemis laring bukan merupakan tanda patognomonis refluks laringofaring tetapi $>50 \%$ penderita refluks laringofaring terdapat eritema/hiperemis. Beberapa faktor yang menjadi penyulit untuk penilaian eritema/hiperemis pada refluks laringofaring disebabkan oleh karena jenis endoskopi dan sumber cahaya yang digunakan. Pada penelitian ini digunakan endoskopi serat lentur yang dinyatakan paling sensitif dan spesifik untuk menilai kelainan laring. ${ }^{3,4}$

Edema subglotik atau pseudosulkus vokalis merupakan gambaran bayangan pita suara yang terjadi di bawah plika vokalis. Pseudosulkus berupa konkavitas dari tepi medial pada plika vokalis diakibatkan oleh fibrosis dan jaringan yang hilang. Pseudosulkus dilaporkan ditemukan pada $90 \%$ kasus refluks laringofaring, sedangkan pada penelitian ini ditemukan pada 12/26 subjek penelitian. ${ }^{1-3}$

Bila plika vokalis dan ventrikularis mengalami edema yang diakibatkan oleh kontak dengan zat asam, batas antara keduanya menjadi tidak jelas digambarkan sebagai obliterasi ventrikular. Pada penelitian ini obliterasi ventrikular ditemukan pada 19/26 subjek.

Selain oleh karena paparan asam, kerusakan mukosa laring juga dapat disebabkan oleh $H$. pylori. Mekanisme kerusakan yang disebabkan oleh $H$. pylori belum jelas sepenuhnya, namun beberapa teori telah dikemukakan, di antaranya karena urease yang diproduksi oleh $H$. pylori yang akan menyebabkan katalisis urea menjadi amonia. Amonia diperlukan untuk bertahan hidup pada suasana asam, namun juga dapat merusak barier mukosa sehingga merusak epitel. Selain itu, sitotoksin yang diproduksi oleh $H$. pylori juga berperan pada kerusakan epitel. Enzim mukolitik (misalnya protease bakteri, lipase) juga terlibat dalam penipisan lapisan mukosa yang menyebabkan epitel lebih rentan untuk terjadi kerusakan oleh karena paparan asam. Selain itu, sitokin yang dihasilkan sebagai respons inflamasi juga berperan pada kerusakan mukosa. ${ }^{6,7}$

Skor STR pascaterapi pada kedua kelompok perlakuan tidak memperlihatkan perbedaan yang bermakna. Menurut Koufman dkk. ${ }^{2}$ hasil temuan endoskopis pada penderita refluks laringofaring akan mengalami perbaikan yang lebih lambat bila dibandingkan dengan berkurangnya gejala refluks laringofaring. Perbaikan temuan endoskopis tidak harus selalu berhubungan dengan perbaikangejala, dikatakan resolusi komplet temuan endoskopis dapat terjadi seteah pengobatan minimum 6 bulan.

Tes HpSA dilakukan pada semua subjek dan pascaterapi pada kedua kelompok, didapatkan hasil tes HpSA negatif sebanyak 92\%. Tingkat eradikasi H.pylori dengan regimen ini hampir serupa dengan beberapa penelitian lain. Lam dkk. ${ }^{14}$ mendapatkan tingkat eradikasi $H$. pylori sebesar $92,5 \%$ pada penderita dispepsia dengan pemberian terapi kombinasi amoksisilin dengan klaritromisin.

Klaritromisin merupakan antibiotik yang paling banyak digunakan untuk eradikasi $H$. pylori dikombinasi dengan antibiotik lain, amoksisilin atau metronidazol. Klaritromisin memiliki efek antinflamasi dan antibakteri. Klaritromisin dapat menghambat produksi IL-8 yang diinduksi infeksi H. pylori. Beberapa penelitian menunjukkan bahwa tingkat eradikasi $H$. pylori lebih costeffective dibandingkan dengan terapi PPI ataupun $\mathrm{H} 2$-antagonis jangka panjang. ${ }^{11,12}$

Pada saat penilaian dengan menggunakan endoskopi ditemukan juga kelainan pada tonsila lingualis berupa hipertrofi dan rinosinusitis. Juga didapatkan hipertrofi dan edema pada mukosa hidung dan sinus paranasal, disertai keluarnya sekret purulen yang persisten dan efusi sinus. Pemeriksaan rinolaringoskopi pada 24/26 subjek penelitian terdapat hipertrofi tonsila lingualis dan perbaikan derajat tonsila lingualis pascaterapi. Mamede dkk. ${ }^{18}$ menemukan hipertrofi tonsila lingualis memiliki hubungan bermakna dengan refluks laringofaring.

Didapatkan 11/26 penderita juga menderita rinosinusitis. Pascaterapi kelompok perlakuan terdapat perbaikan rinosinusitis. Hasil ini sesuai dengan beberapa penelitian lain yang mendukung bahwa penderita GERD cenderung mengalami rinosinusitis. Gejala rinosinusitis menunjukkan perbaikan dengan terapi antirefluks. ${ }^{17}$

Selain dari refluks laringofaring, rinosinusitis juga dapat disebabkan oleh infeksi $H$. pylori di daerah hidung serta sinus paranasal. Morinaka dkk. ${ }^{19}$ mendapatkan $19 \%$ penderita rinosinusitis terdapat infeksi $H$. pylori pada jaringan mukosa hidung dan sinus maksilaris. Penelitian tersebut menyimpulkan bahwa $H$. pylori dapat ditemukan pada jaringan hidung dan sinus maksilaris.

Dilakukan penilaian kualitas hidup dengan kuesioner RQS. Terdapat perbaikan kualitas hidup pascaterapi kedua kelompok penelitian.namun berdasarkan uji statistik perbaikan kualitas hidup ditemukan pada kelompok perlakuan pertama. 
Gejala yang paling mengganggu subjek penelitian ini yaitu keterbatasan fungsi fisik dan persepsi kesehatan umum. Pengaruh paling besar refluks laringofaring terutama fungsi sosial, pada saat melakukan aktivitas sosial dan keterbatasan dalam mengonsumsi makanan. Keluhan batuk kronik, pembersihan tenggorok, dan kesulitan menelan harus mendapat perhatian khusus pada penderita refluks laringofaring. Manifestasi klinis ini secara negatif memengaruhi kualitas hidup secara fungsional, fisik, dan emosional. ${ }^{20}$

Simpulan, pemberian kombinasi antibiotik kombinasi dan lansoprazol lebih efektif terhadap perbaikan gejala klinis dan kualitas hidup bila dibandingkan dengan tanpa lansoprazol pada refluks laringofaring dengan infeksi $H$. pylori.

\section{Daftar Pustaka}

1. Underbink M, Pham V. Laryngopharyngeal Reflux with an emphasis on diagnostic and therapeutic consideration. Grand Rounds Presentation, UTMB, Dept. of Otolaryngology. 25 Agustus 2009.

2. Belafsky PC, Postma GN, Koufman JA. Laryngopharyngeal reflux symptoms improve before changes in physical findings. Laryngoscope. 2001;111(6):979-81.

3. Koufman JA, Aviv JE, Casiano RR, Shaw GT. Laryngopharyngeal reflux: position statement of the committee on speech, voice, and swallowing disorders of the American Academy of Otolaryngology-Head and Neck Surgery. Otolaryngol Head Neck Surg. 2002;127(1):32-5.

4. Belafsky PC, Postma GN, Koufman JA. The validity and reliability of the reflux finding score (RFS). Laryngoscope. 2001;111(8):1313-7.

5. World Gastroenterology Organization Global Guidelines. H. pylori. August 2010:1-15.

6. Kurtaran H, Uyar ME, Kasapoglu B, Turkay C, Yilmaz T, Akcay A, dkk. Role of Helicobacter pylori in pathogenesis of upper respiratory system diseases. J National Med Assoc. 2008;100(10):1224-30.

7. Fouad T, Rifaat M, Taha Y. Incidence of Helicobacter pylori in patients with laryngopharyngeal reflux disease and its correlation with symptom severity. Egyptian J Surg. 2010;29(2):78-84.

8. Silva JM, Villares CA, Monteiro Mdo S, Colauto C, des Santos AF, Mattar R. Validation of a rapid stool antigen test for diagnosis of Helicobacter pylori infection. Rev Inst Med Trop Sao Paulo. 2010;52(3):125-8.

9. Siupsinskiene N, Adamonis K, Toohill
RJ, Sereika R. Predictors of response to short-term proton pump inhibitor treatment in laryngopharyngeal reflux patients. J Laryngol Otol. 2008;122(11):1206-12.

10. Campo SM, Zullo A, Hassan C, Morini S. Antibiotic treatment strategies for Helicobacter pylori infection. Recent Pat Antiinfect Drug Discov. 2007;2(1):11-7.

11. Kikuchi T, Hagiwara K, Honda Y, Gomi K, Kobayashi T, Takahashi $\mathrm{H}$, dkk. Clarithromycin suppresses lipopolysaccharide-induced interleukin- 8 production by human monocytes through AP-1 and NF-kappa B transcription factors. J Antimicrob Chemother. 2002;49(5):745-55.

12. Ortiz RA, Calafattti SA, Moraes LA, Deguer M, Ecclissato CC, Marchioretto MA. Effect of Helicobacter pylori infection and acid blockade by lansoprazole on clarythromycin bioavailability. Braz J Med Biol Res. 2007;40(3):383-9.

13. Endo H, Yoshida H, Ohmi N, Higuchi $S$. Effects of lansoprazole, clarithromycin and $\mathrm{pH}$ gradient on uptake of [14C]amoxycillin into rat gastric tissue. $\mathrm{J}$ Antimicrob Chemother. 2001;47(4):405-10.

14. Lam SK, Ching CK, Lai KC, Wong BC, Lai CL, Chan CK, dkk. Does treatment of Helicobacter pylori with antibiotics alone heal duodenal ulcer? A randomised double blind placebo controlled study. Gut. 1997;41(1):43-8.

15. Gustavson LE, Kaiser JF, Edmonds AL, Loche CS, De Bartolo ML, Schnech DW. Effect of omeprazole on concentrations of clarithromycin in plasma and gastric tissue at steady state. Antimicrob Agents Chemother. 1995;39(9):2078-83.

16. Qadeer MA, Swoger J, Milstein C, Hicks DM, Ponsky J, Richter JE, dkk. Correlation between symptoms and laryngeal signs in laryngopharyngeal reflux. Laryngoscope 2005;115(11):1947-52.

17. DiBaise JK, Sharma VK. Does gastroesophageal reflux contribute to the development of chronic sinusitis? a review of the evidence. Dis Esophagus. 2006;19(6):419-24.

18. Mamede RC, De Mello-Filho FV, Vigario LC, Dantas RO. Effect of gastroesophageal reflux on hypertrophy of the base of the tongue. Otolaryngol Head Neck Surg. 2000;122(4):607-10.

19. Morinaka S, Ichimiya M, Nakamura $H$. Detection of Helicobacter pylori in nasal and maxillary sinus spesimens from patients with chronic sinusitis. Laryngoscope. 2003;113(9):1557-63. 
Yanti N.: Efektivitas Pemberian Antibiotik Disertai Lansoprazol pada Refluks Laringofaring dengan Infeksi Helicobacter pylori

20. Carrau RL, Khidr A, Gold KF, Crawley JA, Hillson EM, Koufman JA, dkk. Validation of a-quality-of-life instrument for laryngopharyngeal reflux. Arch Otolaryngol Head Neck Surg. 2005;131(4):315-20. 